Volume 10, Nomor 2, November 2018, pp 117-138 Copyright (C) 2017 Jurnal Akuntansi Maranatha, Program Studi Akuntansi, Fakultas Ekonomi, Universitas Kristen Maranatha. ISSN 2085-8698 | e-ISSN 2598-4977. http://journal.maranatha.edu

\title{
Analisis Sistem Pengendalian Internal Melalui Audit Berbasis Risiko (ABR) Oleh Aparat Pengawas Intern Pemerintah (APIP) Dalam Mencapai Target Rencana Pembangunan Jangka Menengah Daerah (RPJMD) Studi Kasus pada Inspektorat Kota Banjarbaru
}

\author{
Mujennah \\ STIEI Banjarmasin \\ mujennah@stiei-kayutangi-bjm.ac.id \\ Budi Artinah \\ STIEI Banjarmasin \\ budi@stiei-kayutangi-bjm.ac.id
}

\begin{abstract}
This research explains the role of APIP in carrying out, its functions and duties to achieve the target of Regional Medium Term Plan (RPJMD) 2016-2020. Inspectorate of Banjarbaru City as an element of local government oversight is required to act as an institution capable of improving the quality of supervision on the way of regional development, so as to realize good governance and clean governance. Quoted from the RENSTRA Inspektorat Banjarbaru City there are still strategic issues that can hamper the implementation of the vision mission RPJMD mission in Inspectorate Banjarbaru City. These strategic issues include many findings and recommendations of the results of the investigation that have not been followed up, the lack of strict sanctions on the management of performance and internal control is not good, the quality of public services should still be improved, supervision procedures have not run well, commitment and motivation APIP still needs to be improved. In addition, the Inspectorate of Banjarbaru City has limited resources so it must be able to work efficiently and effectively. as well as the non-implementation of Risk-Based Audit approaches for all functional functional officials. Through an effective internal control system and effective RSP audit implementation is expected to assist APIP's role in implementing the RPJMD 2016- 2020 to reduce strategic issues and mitigate risk to acceptable limits.
\end{abstract}

Keywords: Risk Based Audit (RBA), Government Internal Control System (SPIP), Inspectorate, Good Governance (GC), Clean Governance (CG), Government Internal Supervisory Apparatus (APIP) 


\section{Pendahuluan}

Grand Design Reformasi Birokrasi adalah rancangan induk yang berisi arah kebijakan pelaksanaan reformasi birokrasi nasional untuk kurun waktu 2010-2025. Sasaran Reformasi birokrasi sesuai dengan Peraturan Presiden No. 81 Tahun 2010 yaitu untuk mewujudkan tata pemerintahan yang bersih dan bebas KKN, terwujudnya peningkatan kualitas pelayanan publik, serta meningkatnya kapasitas dan akuntabilitas kinerja. Salah satu target perubahan yang diharapkan mampu menjadi manajemen perubahan (change management) yaitu area Sumber Daya Manusia Aparatur Negara. SDM aparatur yang berintegritas, netral, kompeten, capable, profesional, berkinerja tinggi dan sejahtera. Inspektorat Kota Banjarbaru yang memegang amanat dari Pemerintah sebagai Aparat Pengawas Intern Pemerintah (APIP) telah menyusun Rencana Strategis (Renstra) Tahun 20162020 untuk melaksanakan tugas, fungsi dalam mengawasi pencapaian target Rencana Pembangunan Jangka Menengah Daerah (RPJMD) Kota Banjarbaru. Mengacu pada Peraturan Menteri Dalam Negeri Republik Indonesia Nomor 110 Tahun 2017 tentang kebijakan pengawasan penyelenggaraan pemerintah daerah tahun 2018 pasal 5 bahwa "pelaksanaan kebijakan pengawasan penyelenggaraan pemerintah daerah sebagaimana dimaksud dalam pasal 4, sesuai dengan kewenangannya dilakukan oleh Inspektorat daerah kabupaten/kota. Sejalan dengan pelaksanaan tugas dan fungsi Inspektorat Kota Banjarbaru masih terdapat isu-isu strategis (RENSTRA Inspektorat Kota Banjarbaru 2016-2020) pada sektor pengawasan yaitu tingkat kepatuhan SKPD terhadap peraturan \& perundang- undangan masing sangat kurang ,belum maksimalnya peran APIP sebagai pengawas internal pemerintah daerah, masih banyak temuan dan rekomendasi hasil pemeriksaan yang belum ditindaklanjuti, belum adanya sanksi yang tegas terhadap pengelolaan kinerja dan pengendalian internal yang kurang baik, kualitas pelayanan publik masih harus ditingkatkan, prosedur pengawasan belum dijalankan dengan baik, komitmen dan motivasi APIP masih perlu ditingkatkan. Selain itu Inspektorat Kota Banjarbaru mempunyai keterbatasan sumber daya yang dimiliki sehingga harus dapat bekerja secara efisien dan efektif. Bagi pimpinan Aparat Pengawas Intern Pemerintah (APIP), kemampuan obrik dalam mengelola risiko (ABR) dapat digunakan untuk menentukan prioritas dan dianggap paling tepat dalam upaya mengalokasikan waktu dan pengawasan atas sumber daya manusia yang terbatas. Audit berbasis risiko merupakan sebuah metode yang dapat mengukur risiko, mengevaluasi penyimpangan, menilai efektivitas, melaksanakan pelaporan, untuk menentukan apakah sistem kontrol manajemen memiliki karakteristikkarakteristik berikut ini; fleksibilitas, ketepatan waktu, dan akuntabilitas sehingga mampu memberikan nilai tambah (value added). Inspektorat dalam hal ini selaku APIP, dalam menjalankan pengawasan sebaiknya mampu menelaah lebih rinci elemen kontrol atas risiko, menentukan tujuan sistem pengendalian internal untuk mencapai tujuan dalam menentukan kesesuaian dengan kebijakan organisasi, memastikan ketaatan dengan persyaratan internal atau eksternal, memeriksa dan manganalisis sistem pengendalian untuk menentukan kewajaran.

\section{Perumusan Masalah}

Berdasarkan perumusan permasalahan di atas maka yang menjadi tujuan dari penelitian ini adalah sebagai berikut: mengetahui proses sistem pengendalian internal pemerintah (SPIP) dalam "pelaksanaan kebijakan pengawasan penyelenggaraan pemerintah daerah" di Inspektorat Kota Banjarbaru, mengetahui proses pelaksanaan Audit Berbasis Risiko (ABR) di Inspektorat Kota Banjarbaru, mengetahui bagaimana peran APIP sebagai 
pengawas dalam Rencana Pembangunan Jangka Menengah Daerah (RPJMD) tahun 2016- 2020 di Inspektorat Kota Banjarbaru.

\section{Tujuan Penelitian}

Berdasarkan perumusan permasalahan di atas maka yang menjadi tujuan dari penelitian ini adalah sebagai berikut:

1. Mengetahui proses sistem pengendalian internal pemerintah (SPIP) di Inspektorat Kota Banjarbaru melalui Audit Brebasis Risiko (ARB)?

2. Mengetahui proses pelaksanaan Audit Berbasis Risiko (ARB) di Inspektorat Kota Banjarbaru?

3. Mengetahui peran APIP dalam mencapai target Rencana Jangka Menengah Daerah (RPJMD) di Inspektorat Kota Banjarbaru?

\section{Manfaat Penelitian}

Berdasarkan tujuan penelitian di atas maka manfaat penelitian yang diharapkan adalah:

a. Bagi pemerintah

Sebagai masukan bagi pemerintah dalam menilai efisiensi dan efektivitas penerapan sistem pengendalian internal pemerintah daerah (SPIP) di lingkungan Aparat Pengawas Intern Pemerintah (APIP)

b. Bagi akademis

Sebagai pengetahuan mengenai kegiatan pengendalian internal dan impelementasi audit berbasis risiko serta mengetahui peran aparat pengawas intern pemerintah (APIP) dalam mencapai target Rencana Pembangunan Jangka Menengah (RPJMD) pada Inspektorat Kota Banjarbaru.

\section{Kerangka Teoritis dan Hipotesis}

\section{Audit}

Menurut Standar Audit Intern Pemerintah Indonesia (SPIP) "Audit adalah proses identifikasi masalah, analisis, dan evaluassi yang dilakukan secara independen, objektif dan profesional berdasarkan standar audit, untuk menilai kebenaran, kecermatan, krediblitas, efektivitas, efisiensi dan keandalan informasi pelaksanaan tugas dan fungsi instansi pemerintah"

\section{Internal Audit}

Institute of Internal Auditor (IIA) mendefenisikan internal audit sebagai aktivitas independen, keyakinan objektif dan konsultasi yang dirancang untuk memberi nilai tambah dan meningkatkan operasi organisasi. Audit tersebut membantu organisasi mencapai tujuannya dengan menerapkan pendekatan yang sistematis dan disiplin untuk mengevaluasi dan meningkatkan efektivitas proses pengelolaan resiko, kecukupan kontrol, dan pengelolaan organisasi. 2010.A1 Rencana penugasan aktivitas internal audit harus didasarkan pada penilaian risiko yang terdokumentasi, dilaksanakan sekurangkurangnya setiap tahun. 2120. A1 Berdasarkan hasil penentuan risiko aktivitas internal audit haruslah mengevaluasi kecukupan dan efektivitas kontrol yang mencakup tata kelola, operasi dan sistem informasi organisasi.

\section{Standar Audit Intern Pemerintahan Indonesia (SAIPI)}

Standar Audit Pemerintahan merupakan standar untuk melakukan audit atas semua kegiatan pemerintah. Standar-standar yang menjadi pedoman dalam audit kinerja terhadap lembaga pemerintah menurut SAIPI adalah sebagai berikut: Standar umum nomor 2100 mengenai kewajiban mengikuti standar audit dan meningkakan kompetensi, Standar pelaksanaan nomor 3000 yaitu mengelola kegiatan antara lain; menyusun Renstra dan PKPT, menetapkan kebijakan dan prosedur, koordinasi dengann auditor lain serta menindaklanjuti pengaduan masyarakat, Standar pelaksanaan nomor 3100 yaitu mengenai sifat kerja antara lain yaitu perbaikan tata kelola, manajemen risiko dan pengendalian intern, Standar pelaksanaan nomor 3200 
yaitu mengenai perenacnaan antara lain sasaran, ruang lingkup, metodologi dan sumber daya, program kerja audit intern dan evaluasi SPI, Standar pelaksanaan nomor 3300 yaitu pelaksanaan yang meliputi KKA, identifikasi, analisis dan evaluasi dan simpulan, dokumentasi dan supervise, Standar komunikasi nomor 4100 mengenai pemantauan yaitu tindak lanjut yang meliputi pemantauan, tindak lanjut atas hasil rekomendasi

\section{Sistem Pengendalian Internal}

Menurut konsep COSO, pengendalian intern adalah proses yang mencakup kegiatan operasional organisasi dan merupakan bagian integral dari kegiatan manajemen. Sistem pengendalian internal yang baik memiliki tujuan untuk memberikan reliablilitas atas pelaporan keuangan, efisiensi dan efektivitas operasi, dan ketaatan pada hukum dan peraturan (Arens 20011, 370-371). Menurut Mulyadi $(2000,132)$ menyatakan pengertian efektivitas sebagai berikut: "Efektivitas merupakan hubungan antara keluaran dengan tujuan atau sasaran yang harus dicapai.". Sistem pengendalian internal adalah suatu proses yang dijalankan oleh internal audit dan personel lain dari suatu entitas yang terdiri atas kebijakan dan prosedur untuk memberikan keyakinan memadai tentang pencapaian tujuan efektivitas dan efisiensi operasi, keandalan pelaporan keuangan, kepatuhan terhadap hukum dan peraturan yang berlaku.

\section{Internal Audit dan Audit Berbasis Risiko (RBA)}

Menurut David M. Griffths, PhD, FCA (Risk Based Internal Auditing An Introduction,2006) "Internal auditing provides an independent and objective opinion to an organisations management as to whether its risks are being managed to acceptable levels.

Audit berbasis risiko (RBA) adalah sebuah metologi yang menghubungkan audit internal dengan seluruh kerangka manajemen risiko yang memungkinkan proses audit internal mendapatkan keyakinan memadai bahwa manajemen risiko organisasi telah dikelola dengan memadai sehubungan dengan risiko yang dapat diterima (risk appetite). SA-IPI (3100) - Sifat Kerja Kegiatan Audit Intern menjelaskan kegiatan audit intern harus dapat mengevaluasi dan memberikan kontribusi pada perbaikan tata kelola sektor publik, manajemen risiko dan pengendalian intern dengan menggunakan pendekatan sistematis dan disiplin. Risiko perlu dikelola dengan tepat dan wajar melalui pengawasan secara berkala. Pengelolaan risiko dengan tepat dapat memberikan jaminan yang memadai bahwa kegiatan operasional dapat berlangsung secara optimal sesuai dengan tujuan perusahaan. The IIA Standards for the professional Practice of Internal Auditing 2011, 29-30) Standard 2110 Governance menyatakan bahwa kegiatan audit internal mampu menilai dan membuat recomendasi yang sesuai untuk meningkatkan proses tata kelola dalam pencapaiannya tujuan berikut: Mempromosikan etika dan nilai- nilai yang sesuai dalam perusahaan, Memastikan manajemen memiliki kinerja organisasi yang efektif dan Akuntable, Mengkomunikasikan risiko dan pengendalian informasi ke setiap bagian di perusahaan dan mengkoordinasikan aktivitas dan informasi serta komunikasi antara internal auditor dan manajemen eksternal.

Aparatur Pengawas Intern Pemerintah (APIP) dan Penerapan Audit Berbasis Risiko (RBA)

Tugas APIP menurut Peraturan Kemendagri No. 83 Tahun 2017 yaitu melaksanakan pengawasan penyelenggaran pemerintah daerah baik berupa usaha, tindakan, dan kegiatan yang ditujukan untuk menjamin penyelenggaraan pemerintahan daerah berjalan secara efisien dan efektif sesuai dengan ketentuan peraturan perundangundangan. Pasal 11 dan 59 Peraturan 
Pemerintah No. 60 Tahun 2008 menyatakan peran apip dalam hal: Memberikan keyakinan yang memaddai atas ketaatan, kehematan, efisiensi dan efektivitas pencapaian tujuan penyelenggaraan tugas dan fungsi IP (assurance activities), memberikan peringatan dini dan meningkatkan efektivitas manajemen risiko dalam penyelenggaraan tugas dan fungsi Intern Pemerintah dan memelihara dan meningkatkan kualitas tata kelola penyelenggaraan tugas dan fungsi Intern Pemerintah. Berdasarkan Surat Ka BPKP No. S-106/K/JF/2014 mengenai Pembinaan Kapabilitas APIP dengan pendekatan IACM: Internal Audit Capability Model (IA-CM) adalah suatu kerangka kerja yang mengindentifikasi aspek-aspek fundamental yang dibutuhkan untuk pengawasan intern yang efektif di sektor publik yang dikembangkan oleh IIA. Enam elemen penting bagi aktivitas audit internal yang diidentifikasi dalam model IACM yaitu : 1) Services and Role of Internal Auditing (Peran dan Layanan) , 2) People Management (Manajemen SDM), 3) Professional Practices (Praktik Profesional), 4) Performance Management and Accountability (Manajemen Kinerja dan Akuntabilitas), 5) Organizational Relationships and Culture (Hubungan dan Budaya Organisasi), 6) Governance Structure (Struktur Tata Kelola).

\section{Sistem Pengendalian Internal (COSO) Enterprise Resources Management (ERM)}

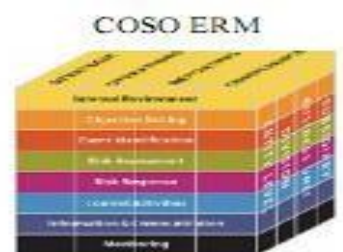

Sumber: Treadway Of Comission 2004

1. Lingkungan Pengendalian (Internal Environment)

2. Penetapan Tujuan (Objective Serting)

3. Identifikasi Kejadian

4. Penilaian Risiko (Risk Assesment)

5. Risk Response (Respon Terhadap Risiko)

6. Aktivitas Pengendalian (Control Activities)

7. Informasi dan Komunikasi (Information and Communications)

8. Pengawasan (Monitoring)

\section{Profil Perusahaan}

\section{Sejarah Inspektorat}

Awal dibentuknya Inspektorat Kota Banjarbaru yaitu tahun 1999. Inspektorat Kota Banjarbaru sebagai salah satu Lembaga Teknis daerah yang ada di lingkungan Pemerintah Kota Banjarbaru dibentuk, terakhir berdasarkan Peraturan Daerah (PERDA) Kota Banjarbaru Nomor 6 Tahun 2013 tentang Pembentukan Organisasi dan Tata Kerja Lembaga Teknis Daerah Kota Banjarbaru dan Peraturan Walikota Banjarbaru Nomor 44 Tahun 2013 tentang Tugas Pokok, Fungsi dan Tata Kerja Inspektorat Kota Banjarbaru. Inspektorat Kota Banjarbaru merupakan unsur pengawas penyelenggaraan Pemerintah Daerah yang dipimpin oleh seorang Inspektur, berkedudukan di bawah dan bertanggung jawab langsung kepada Walikota Banjarbaru dengan tugas pokok membantu Walikota Banjarbaru mengawasi pelaksanaan urusan pemerintahan dan menyelenggarakan pembinaan kegiatan pemerintahan daerah sesuai dengan peraturan perundang-undangan yang 
berlaku. Pasal 59 Peraturan Pemerintah Nomor 60 Tahun 2008 tentang Sistem Pengendalian Intern Pemerintah, Peraturan kepala BPKP Nomor 16 Tahun 2015 tentang Pedoman teknis peningkatan Kapabilitas Aparat Pengawasan Intern Pemerintah (APIP), Surat tugas Kepala Perwakilan BPKP Provinsi Kalimantan Selatan Nomor ST-270/PW16/6/2016 tanggal 12 Oktober 2016.

\section{Renstra}

Rencana Strategis dokumen perencanaan yang mampu menghasilkan suatu rumusan strategis, kebijakan, program dan kegiatan sesuai dengan tugas dan fungsi Inspektorat ,sehingga dapat lebih terarah dan terpadu guna mendukung terwujudnya tujuan dan sasaran pembangunan Kota Banjarbaru pada periode RPJMD 2016- 2021. Visi Inspektorat adalah terwujudnya pengawasan yang berintegritas dan misi Inspekotorat Kota Banjarbaru adalah melaksanakan reformasi birokrasi yang berorientasi kepada pelayanan publik dan tata kelola pemerintahan yang berbasis teknologi informasi.

\section{Metode Penelitian}

Metode yang digunakan dalam desain penelitian ini adalah deskriptif analistis dimana penulis mencoba untuk menjelaskan, meringkaskan kondisi-kondisi objek dan variabel signifikan yang ditemui pada saat penelitian. Penulis juga melaksanakan wawancara dan studi literatur untuk memenuhi penilaian terhadap pengendalian internal dan implementasi audit berbasis risiko di lingkungan dalam pencapaian target Rencana Pembangunang Jangka Menengah 2016-2020 di Inspektorat kota Banjarbaru, dengan melakukan wawancara dan studi literatur. Sumber data yang digunakan dalam penelitian ini adalah: a. Data Primer yang diperoleh dengan melakukan wawancara dan kuesioner dengan pihak terkait pelaksanaan fungsi pengawasan, pelayanan publik dan tata kelola pemerintahan yang baik serta laporan pelaksanaan fungsi pengelola keuangan dan barang pemerintah daerah di Inspektorat Kota Banjarbaru yaitu dengan anggota tim internal audit perusahaan perusahaan, untuk mengetahui kebijakan apa saja yang telah digunakan, peraturan mengenai internal kontrol, dan audit berbasis risiko.

b. Data Sekunder yang diperoleh dengan mencari teori-teori dan ide-ide pokok pikiran dari buku, literatur, artikel, laporan keuangan dan jurnal yang terkait.

\section{Teknik Pengumpulan Data}

a. Studi Literatur

Studi literatur dilakukan dengan mengumpulkan dan mempelajari bukubuku, tulisan ilmiah, catatan-catatan atau laporan tertulis dan diarahkan untuk memperoleh landasan teori yang akan digunakan dalam menganalisis sistem pengendalian internal dan halhal yang mempunyai hubungan dengan masalah yang diteliti, Peraturan perundang-undangan, Surat Keputusan Pemerintah dan peraturan terkait lainnya

b. Studi Lapangan

Melalui penelitian di lapangan untuk mendapatkan data melalui observasi, wawancara, kuesioner dan diskusi dengan pihak-pihak yang terkait dalam kegiatan pelaksanaan fungsi pengawasan, pelayanan publik dan tata kelola pemerintahan serta fungsi pengelolaan keuangan dan barang pemerintah daerah. 


\section{Hasil Penelitian dan Pembahasan}

\author{
Analisis Dan Pembahasan \\ Analisis Sistem Pengendalian Intern \\ di Inspektorat Kota Banjarbaru
}

Tabel 1

Interval Skor Tingkat Maturitas SPIP

\begin{tabular}{|c|c|c|}
\hline No & $\begin{array}{l}\text { Tingkat } \\
\text { Maturitas }\end{array}$ & Interval Skor \\
\hline 0 & $\begin{array}{l}\text { Dalam } \\
\text { Penataan }\end{array}$ & $\begin{array}{l}\text { Kurang dari } 1,0 \quad(0< \\
\text { skor }<1,0)\end{array}$ \\
\hline 1 & Rintisan & $\begin{array}{l}1,0 \text { s/d kurang dari } 2,0 \\
(1,0 \leq \text { skor }<2,0)\end{array}$ \\
\hline 2 & Berkembang & $\begin{array}{l}2,0 \mathrm{~s} / \mathrm{d} \text { kurang dari } 3,0 \\
(2,0 \leq \text { skor }<3,0)\end{array}$ \\
\hline 3 & Terdefinisi & $\begin{array}{l}3,0 \text { s/d kurang dari } 4,0 \\
(3,0 \leq \text { skor }<4,0)\end{array}$ \\
\hline 4 & $\begin{array}{l}\text { Terkelola Dai } \\
\text { Terukur }\end{array}$ & $\begin{array}{l}\text { n4,0 s/d kurang dari } 4,5 \\
(4,0 \leq \text { skor }<4,5)\end{array}$ \\
\hline 5 & Optimum & $\begin{array}{l}\text { Antara } 4,5 \text { s/d } 5,0(4,5 \leq \\
\text { skor } \leq 5)\end{array}$ \\
\hline
\end{tabular}

Setiap fokus terbagi atas 5 karakter yang sifatnya meningkat dari "Dalam Penataan" (nilai=0), "Rintisan" (nilai=1), "Berkembang" (nilai=2), "Terdefinisi" (nilai=3), "Terkelola dan Terukur" (nilai=4), dan "Optimum" (nilai $=5$ ). Karakteristik umum masing-masing tingkatan sebagaimana terlihat pada Tabel 1 .

Hasil review dan analisi penulis mengenai Sistem Pengendalian Internal di Inspektorat Kota Banjarbaru yaitu : a. Lingkungan Pengendalian (Pasal 4, PP No 60 Tahun 2008)

Lingkungan Pengendalian intansi pemerintah yang mempengaruhi efektivitas pengendalian intern. Pimpinan instansi pemerintah wajib menciptakan dan memelihara lingkungan pengendalian yang menimbulkan perilaku positif dan kondusif untuk penerapan sistem pengendalian intern dalam lingkungan kerjanya. Lingkungan pengendalian merupakan fondasi bagi efektivitas penerapan komponen SPIP lainnya.

Penilaian tingkat maturitas unsur lingkungan pengendalian dilakukan terhadap delapan fokus penilaian sebagai berikut:

1. Penegakan Integritas dan Nilai Etika

Fokus Penilaian Penegakan Integritas dan Nilai Etika memenuhi kriteria pada tingkat "Terdefinisi". Inspektorat Kota Banjarbaru telah memiliki kode etik yang ditetapkan dengan Peraturan Walikota Banjarbaru Nomor 17 tahun 2013 tentang Kode Etik PNS di Lingkungan Pemerintah Kota Banjarbaru yang antara lain mengatur mengenai: Prinsip dan kode etik PNS (dalam bernegara, berorganisasi, bermasyarakat, terhadap diri sendiri, dan sesama PNS). Majelis kode etik PNS, Penanganan pelanggaran Kode Etik PNS, Sanksi pelanggaran, dan rehabilitasi. Pegawai secara umum telah berperilaku sesuai dengan aturan tersebut. Komitmen terhadap penerapan kebijakan/prosedur tentang Aturan Perilaku diwujudkan dalam Pakta Integritas yang ditandatangani oleh pejabat struktural. Pengenaan sanksi disiplin terhadap pelanggaran Aturan Perilaku telah 
diterapkan. Penerapan dan penegakan kode etik telah dilaksanakan secara berkala sebagai bagian dari pengawasan langsung oleh atasan dan Sistem Penilaian Kinerja Pegawai. Namun demikian, masih terdapat hal-hal yang perlu diperbaiki yaitu: pemantauan atau evaluasi penerapan Aturan Perilaku (Kode Etik) belum dilaksanakan secara berkala dan terdokumentasi, pelaksanaan penegakan integritas dan nilai etika belum dilaksanakan secara otomatis dengan berbasis teknologi informasi, termasuk pengawasannya dan tindaklanjut perbaikan secara berkelanjutan.

2. Komitmen Terhadap Kompetensi Komitmen terhadap kompetensi telah memenuhi kriteria pada tingkat "Terdefinisi". Inspektorat Kota Banjarbaru telah memiliki dokumen kebijakan/prosedur yang mengatur mengenai standar kompetensi untuk seluruh jabatan struktural dan pelaksana yang dituangkan dalam dokumen standar kompetensi jabatan dan dokumen analisa jabatan. Secara umum pejabat yang ada telah memenuhi kualifikasi jabatan, terutama bagi eselon 2 yang rekruitmen melalui tes assessment. Namun demikian, masih terdapat area yang memerlukan perbaikan antara lain: evaluasi pemberlakuan kebijakan atau prosedur tentang standar kompetensi belum dilaksanakan secara berkala, terstruktur dan terdokumentasi. belum terdapat pemantauan berkelanjutan dan evaluasi secara otomatis atas kebijakan atau prosedur atas penerapan standar kompetensi.

3. Kepemimpinan Yang Kondusif Penilaian terhadap kepemimpinan yang kondusif telah dapat memenuhi kriteria pada tingkat "Terdefinisi". Inspektorat Kota Banjarbaru telah memiliki kebijakan dan prosedur mengenai sistem manajemen kinerja mengacu kepada Perpres No. 29 Tahun 20xx tentang Sistem Akuntabilitas Kinerja Instansi Pemerintah (SAKIP). Penerapan SAKIP tersebut antara lain terlihat dari adanya Renstra, perjanjian kinerja, pengukuran kinerja, pelaporan kinerja melalui LAKIP, reviu dan evaluasi kinerja. Penilaian kinerja pegawai antara lain dilakukan melalui Sasaran Kinerja Pegawai (SKP). Meski demikian, masih terdapat hal-hal yang memerlukan perbaikan yaitu terkait : evaluasi atas kebijakan dan prosedur mengenai sistem manajemen kinerja dan penerapannya belum dilaksanakan secara terdokumentasi dan berkala. Belum terdapat continuous improvement atas sistem manajemen kinerja dan belum terdapat pemantauan secara otomatis/online oleh pimpinan organisasi.

4. Struktur Organisasi yang Sesuai Kebutuhan

Penilaian terhadap struktur organisasi yang sesuai dengan kebutuhan telah dapat memenuhi kriteria pada tingkat "Terkelola dan Terukur". Struktur Organisasi dan Tata Laksana Inspektorat Kota Banjarbaru telah ditetapkan dengan Peraturan Walikota tentang Kedudukan, Susunan Organisasi, Tugas dan Fungsi serta Tata Kerja di lingkungan Inspektorat Kota Banjarbaru. Evaluasi atas implementasi struktur organisasi beserta tata laksananya telah dilaksanakan dengan melibatkan Kementerian PAN dan RB. Namun demikian, terdapat areas of 
improvement mengenai belum adanya dokumen tindak lanjut perbaikan secara berkelanjutan atas hasil evaluasi.

5. Delegasi Wewenang dan Tanggung Jawab

Penilaian terhadap pendelegasian wewenang dan tanggung jawab telah memenuhi kriteria pada tingkat "Terdefinisi". Unit organisasi di lingkungan Inspektorat Kota Banjarbaru telah melaksanakan kebijakan dan prosedur mengenai pendelegasian wewenang seperti yang tercantum pada Peraturan Walikota Banjarbaru Nomor 24 Tahun 2010 tentang Tata Naskah Dinas di Lingkungan Inspektorat Kota Banjarbaru. Pelaksanaan pendelegasian wewenang tersebut, dilakukan melalui Penunjukan Pejabat Pengganti apabila ada pejabat yang berhalangan tetap dan berhalangan sementara. Selanjutnya, mekanisme pelaporan kepada pemberi delegasi atas pelaksanaan pendelegasian tersebut dilakukan secara tertulis. Hal-hal yang memerlukan peningkatan yaitu evaluasi atas penerapan kebijakan delegasi wewenang dan tanggung jawab secara umum belum dilaksanakan secara berkala, terdokumentasi, serta belum dilakukan secara otomatis dengan berbasis teknologi informasi.

6. Kebijakan Pembinaan SDM

Penilaian terhadap kebijakan pembinaan SDM telah memenuhi kriteria pada tingkat "Terdefinisi". Inspektorat Kota Banjarbaru telah melaksanakan kebijakan/prosedur mengenai pembinaan pegawai sebagai bagian kebijakan pembinaan SDM pegawai di Lingkungan Inspektorat Kota Banjarbaru. Kebijakan/ SOP yang ada meliputi serangkaian kebijakan/aturan mengenai pembinaan Sumber Daya Manusia (SDM), dokumen standar kompetensi jabatan untuk Jabatan Struktural, SOP Kepegawaian (SOP Ijin Cuti, SOP Mutasi Pegawai), SOP pengusulan Calon Peserta Diklat, Dokumen Standar Kinerja Pegawai (SKP).

7. Perwujudan Peran APIP yang Efekif

Penilaian terhadap perwujudan peran APIP yang efektif telah dapat memenuhi kriteria pada tingkat "Terdefinisi". Peran APIP dilaksanakan oleh Inspektorat Kota Banjarbaru dengan uraian sebagai berikut: memiliki program kerja pengawasan tahunan yang berisi daftar obyek pemeriksaan dalam satu tahun dan susunan tim pengawas yang melakukan audit, program kerja pengawasan tahunan tersebut telah dikomunikasikan kepada seluruh aparat, Inspektorat Banjarbaru telah dapat memberikan keyakinan yang memadai atas ketaatan, kehematan, efisiensi, efektivitas, pencapaian tujuan penyelenggaraan tugas dan fungsi SKPD, kinerja pengawasan inspektorat telah dilakukan penilaian internal dan hasilnya telah ditindaklanjuti dalam rangka meningkatkan keyakinan yang memadai atas ketaatan, kehematan, efisiensi, efektivitas, pencapaian tujuan penyelenggaraan tugas dan fungsi organisasi secara berkala dan terdokumentasi.

8. Hubungan Kerja yang Baik dengan Instansi Pemerintah Terkait Penilaian terhadap hubungan kerja yang baik dengan instansi terkait telah dapat memenuhi kriteria pada tingkat "Terdefinisi". SKPD di lingkungan Inspektorat Kota 
Banjarbaru telah memiliki dan melaksanakan kebijakan yang mengatur mengenai mekanisme hubungan kerja yang baik dengan SKPD terkait, dengan uraian : SKPD telah memiliki pedoman/kebijakan/SOP terkait dengan tugas dan fungsi SKPD yang melibatkan SKPD lain terkait dengan mekanisme saling uji (pencocokan data dengan unit kerja/unit organisasi yang menangani) seperti SOP rekonsiliasi aset dari BPKAD yang berisi langkah-langkah rekonsiliasi aset antara SKPD dengan bpkad. Pedoman/kebijakan terkait dengan tugas dan fungsi SKPD, yang melibatkan SKPD lain tersebut, telah dikomunikasikan kepada pegawai yang berkepentingan. Kebijakan/ prosedur koordinasi dengan SKPD lain telah diimplementasikan oleh pegawai yang berkepentingan di setiap jenjang level unit kerja dan didokumentasikan. Evaluasi atas penerapan kebijakan terkait hubungan kerja yang baik dengan SKPD lainnya secara umum telah terdokumentasi dengan baik.

\section{b. Penilaian Risiko}

Penilaian risiko adalah kegiatan penilaian atas kemungkinan kejadian yang mengancam pencapaian tujuan dan sasaran instasni pemerintah. Penilaian tingkat maturitas unsur penilaian risiko dilakukan terhadap dua fokus penilaian sebagai berikut:

1. Identifikasi Risiko

Penilaian terhadap identifikasi risiko telah memenuhi kriteria pada tingkat "Terdefinisi". Inspektorat Kota Banjarbaru telah memiliki kebijakan penilaian risiko atau identifikasi risiko yang ditetapkan dengan Surat Edaran Walikota Banjarbaru Nomor
700/01/INSPEKTORAT tentang Penilaian Risiko di Lingkungan Inspektorat Kota Banjarbaru yang berisikan pedoman penilaian risiko di lingkungan Inspektorat Kota Banjarbaru, Inspektorat Kota Banjarbaru telah melakukan identifikasi risiko serta menyusun daftar risiko atas kegiatan utama yang ditetapkan secara formal.

2. Analisis Risiko

Penilaian terhadap analisis risiko telah memenuhi kriteria pada tingkat "Terdefinisi". Inspektorat Kota Banjarbaru telah memiliki kebijakan terkait penilaian risiko/analisis risiko yang ditetapkan dengan Surat Edaran Walikota Banjarbaru Nomor 700/796-SPT/Inspektorat, tanggal 15 September 2017, Kertas kerja penilaian risiko. Pendampingan melakukan penilaian resiko. Kebijakan/pedoman penilaian risiko (analisis risiko) yang ditetapkan secara formal oleh Kepala Daerah. Contoh: Perka BPKP Nomor : PER688/K/D4/2012 tentang Pedoman Pelaksanaan Penilaian Risiko di Lingkungan Instansi Pemerintah. Inspektorat Kota Banjarbaru belum memiliki Rencana Tindak Pengendalian (RTP) atau rencana penanganan risiko atas kegiatan utama yang ditetapkan secara formal.

\section{c. Kegiatan pengendalian}

Kegiatan pengendalian adalah tindakan yang diperlukan untuk mengatasi risiko serta penetapan dan pelaksanaan kebijakan dan prosedur untuk memastikan bahwa tindakan mengatasi risiko telah dilaksanakan secara efektif. Kegiatan pengendalian ditetapkan untuk membantu memastikan bahwa arahan pimpinan instansi pemerintah dilaksanakan dan membantu 
memastikan tindakan yang perlu, telah dilakukan untuk meminimalkan risiko dalam mencapai tujuan Penilaian tingkat maturitas unsur kegiatan pengendalian dilakukan terhadap sebelas fokus penilaian sebagai berikut:

1. Reviu Kinerja

Penilaian terhadap reviu kinerja telah memenuhi kriteria pada tingkat "Terdefinisi", dengan kondisi sebagai berikut: setiap SKPD di lingkungan Inspektorat Kota Banjarbaru telah menetapkan Perjanjian Kinerja, membuat laporan kinerja triwulanan yang berisi laporan pencapaian kinerja organisasi, laporan evaluasi sebagai dokumentasi pelaksanaan evaluasi atas kinerja telah dibuat guna mengidentifikasi permasalahan dan langkah perbaikan untuk peningkatan kinerja tahun berikutnya. Dokumen tersebut telah dikomunikasikan kepada pegawai yang berkepentingan. Namun demikian, masih terdapat hal-hal yang memerlukan perbaikan yaitu: cara/metode pelaksanaan kegiatan belum dikembangkan terus menerus sesuai dengan perubahan untuk meningkatkan kinerja.belum dilakukan pemantauan otomatis/online oleh pimpinan organisasi atas kinerja organisasi/ unit organisasi/ unit kerja.

2. Pembinaan Sumber Daya Manusia Penilaian terhadap sub unsur pembinaan sumber daya manusia telah memenuhi kriteria pada tingkat "Terdefinisi", dengan kondisi : Inspektorat Kota Banjarbaru telah memiliki dan melaksanakan kebijakan/SOP terkait pembinaan sumber daya manusia yang memuat kebutuhan jumlah, persyaratan jabatan, dan standar kinerja pegawai), terdapat pemetaan pegawai setiap tahun, memiliki Standar Kompetensi Jabatan. Kebijakan ttg pemetaan kebutuhan pegawai yang didasarkan pada rencana strategis. Surat Nomor 872/1348/BKPP, tanggal 02 Oktober 2017. Terkait dengan pembinaan SDM, SKP pegawai disusun dengan memperhatikan target kinerja yang telah ditetapkan pada Perjanjian Kinerja dan Renstra. Namun demikian masih terdapat area yang memerlukan perbaikan terkait evaluasi atas capaian kinerja pegawai belum seluruhnya dilaksanakan secara terdokumentasi dan berkala, dan belum dilakukan secara otomatis dengan berbasis teknologi informasi.

3. Pengendalian terhadap Pengelolaan Sistem Informasi

Pengendalian terhadap pengelolaan sistem informasi dinilai pada tingkat "Berkembang". Secara umum, Pemerintah Kota Banjarbaru telah memiliki kebijakan dan SOP yang memuat pengendalian umum dan pengendalian aplikasi berbasis teknologi informasi (TI) antara lain dalam bentuk pedoman pengelolaan TI, buku manual pengoperasian program aplikasi komputer yang digunakan seperti Sistem Informasi Manajemen Daerah (SIMDA). Namun demikian, atas kebijakan pengendalian atas Sistem informasi masih diperlukan perbaikan terkait : kebijakan pengendalian aplikasi hanya ditetapkan terhadap pengendalian aplikasi sistem informasi tertentu/khusus, sedangkan pengendalian aplikasi secara umum/general belum ditetapkan, pengendalian aplikasi sistem informasi Inspektorat Kota 
Banjarbaru belum dikembangkan secara terus menerus dan belum dilakukan pemantauan otomatis/online oleh pimpinan organisasi/unit organisasi/ unit kerja.

4. Pengendalian Fisik atas Aset

Penilaian terhadap sub unsur pengendalian fisik atas aset telah dapat memenuhi kriteria pada tingkat "Terkelola dan Terukur", dengan kondisi: Inspektorat Kota Banjarbaru telah memiliki dan melaksanakan aturan terkait pengelolaan pengamanan aset dengan berpedoman pada Peraturan Daerah Nomor 10 Tahun 2017 tentang Pengelolaan Barang Milik Daerah, memiliki SOP tentang Mekanisme Penatausahaan Barang Milik Daerah (BMD) di Lingkungan Inspektorat Kota Banjarbaru antara lain memiliki daftar BMD dan kartu inventaris ruangan. Penncatatan Aset telah memanfaatkan aplikasi SIMDA, adanya evaluasi atas kebijakan Pengendalian Fisik atas Aset yang dilaksanakan secara berkala dan terdokumentasi.

5. Penetapan dan Reviu Indikator Penilaian terhadap sub unsur penetapan dan reviu indikator telah dapat memenuhi kriteria pada tingkat "Terdefinisi", dengan kondisi : Inspektorat Kota Banjarbaru dan unit organisasi dibawahnya telah memiliki Indikator Kinerja Utama (IKU) yang digunakan untuk mengukur realisasi kinerja. hasil pengukuran IKU dilaporkan pada LAKIP SKPD.Hal yang masih perlu diperbaiki yaitu: Indikator Kinerja Utama (IKU) belum dikembangkan secara terus menerus sesuai dengan perubahan strategis organisasi, IKU yang ditetapkan belum sepenuhnya berorientasi pada outcome, masih berorientasi pada output.

6. Pemisahan Fungsi

Penilaian terhadap sub unsur pemisahan fungsi telah dapat memenuhi kriteria pada tingkat "Terdefinisi", dengan kondisi : Kebijakan Pemisahan fungsi dan tanggungjawab tertuang dalam Struktur organisasi Inspektorat Kota Banjarbaru yang telah ditetapkan dengan Peraturan Walikota tentang Kedudukan, Susunan Organisasi, Tugas dan Fungsi serta Tata Kerja, telah terdapat SOP atas kegiatankegiatan pada unit organisasi yang memisahkan antara fungsi perencanaan, pengawasan, pengendalian, dan kegiatan umum. Namun demikian, terdapat hal yang masih memerlukan perbaikan terkait belum dilaksanakannya evaluasi atas pemisahan tanggung jawab dan fungsi secara berkala dan terdokumentasi.

7. Otorisasi Transaksi dan Kejadian Penting

Penilaian terhadap sub unsur otorisasi transaksi dan kejadian penting telah dapat memenuhi kriteria pada tingkat "Terdefinisi", dengan kondisi Inspektorat Kota Banjarbaru telah memiliki dan mengimplementasikan Peraturan Walikota Nomor 6 tahun 2016 tentang Kebijakan Akuntansi yang mengatur otorisasi transaksi. Namun demikian, masih terdapat hal yang memerlukan perbaikan terkait evaluasi atas kebijakan otorisasi transaksi dan kejadian penting belum dilakukan secara berkala dan terdokumentasi dengan baik.

8. Pencatatan yang Akurat dan Tepat Waktu

Penilaian terhadap sub unsur pencatatan yang akurat dan tepat 
waktu telah dapat memenuhi kriteria pada tingkat "Terkelola dan Terukur", dengan kondisi: SKPD telah memiliki pedoman terkait kewajiban pencatatan transaksi dan kejadian secara akurat dan tepat waktu. Pedoman tersebut telah dikomunikasikan kepada pegawai yang berkepentingan di SKPD. Transaksi dan kejadian penting pada unit kerja Saudara telah dicatat secara akurat dan tepat sesuai pedoman. Evaluasi atas kebijakan pencatatan yang akurat dan tepat waktu yang telah dilaksanakan secara berkala dan terdokumentasi dengan memadai.

9. Pembatasan Akses atas Sumber Daya dan Catatan

Penilaian terhadap sub unsur pembatasan akses atas sumber daya dan catatan telah dapat memenuhi kriteria pada tingkat "Terdefinisi", dengan kondisi Inspektorat Kota Banjarbaru telah melakukan pembatasan akses atas sumber daya dan pencatatan. Pembatasan ini dilakukan dengan menunjuk pegawai yang berwenang melalui SK Walikota. Meski demikian, terdapat hal-hal yang memerlukan perbaikan terkait belum dilaksanakannya evaluasi atas kebijakan pembatasan akses atas sumber daya dan catatan secara berkala dan terdokumentasi.

10. Akuntabilitas Pencatatan dan Sumber Daya

Penilaian terhadap sub unsur pencatatan dan sumber daya telah dapat memenuhi kriteria pada tingkat "Terdefinisi", dengan kondisi: Unit organisasi Inspektorat Kota Banjarbaru telah menunjuk pegawai yang bertanggungjawab atas pencatatan dan sumber daya kebijakan, dengan menerbitkan SK Pengelola Keuangan, SK Pengelola Kepegawaian, SK Pengelola BMD; Pertanggungjawaban atas pencatatan telah dituangkan dalam Laporan Mutasi Barang Persediaan, Daftar BMD, dan Laporan Realisasi Anggaran. Database Kepegawaian yang menunjukkan catatan pengelolaan kepegawaian juga telah diupdate secara rutin. Namun demikian, perlu dilakukan perbaikan terkait evaluasi terhadap akuntabilitas pencatatan dan sumber daya.

11. Dokumentasi yang baik atas Sistem Pengendalian Intern (SPI) serta transaksi dan kejadian penting

Penilaian terhadap sub unsur dokumentasi yang baik atas Sistem Pengendalian Intern (SPI) serta transaksi dan kejadian penting telah memenuhi kriteria pada tingkat "Terdefinisi", dengan kondisi : SKPD telah memiliki kebijakan atau prosedur untuk melakukan dokumentasi atas implementasi/penyelenggaraan SPI serta transaksi dan kejadian penting; Kebijakan ini telah dikomunikasikan ke pegawai yang berkepentingan; Dokumentasi atas implementasi SPI serta transaksi dan kejadian penting telah dilakukan sesuai kebijakan yang ditetapkan. SK Walikota No. 188.45/15/KUM/2017. Namun demikian, terdapat hal-hal yang memerlukan perbaikan terkait: evaluasi secara berkala dan terdokumentasi atas kebijakan pencatatan/dokumentasi atas SPI dan transaksi/kejadian penting belum dilaksanakan dan tidak terdapat pemantauan yang bersifat terus-menerus dan otomatis atas pencatatan dan dokumentasi SPI 
serta transaksi atau kejadian penting.

\section{d. Informasi dan komunikasi}

1. Informasi adalah data yang telah diolah yang dapat digunakan untuk pengambilan keputusan dalam rangka penyelenggaraan tugas dan fungsi intansi pemerintah. Sedangkan komunikasi adalah proses penyampaian pesan atau informasi dengan menggunakan symbol atau lambang tertentu baik secara langsung maupun tidak langsung untuk mendapatkan umpan balik. Penilaian terhadap informasi yang relevan telah dapat memenuhi kriteria pada tingkat "Terdefinisi", dengan kondisi :SKPD telah memiliki dokumen Renstra yang memuat informasi isu isu strategis dan Dokumen Renja yang memuat informasi rinci dan sesuai untuk semua tingkatan Pimpinan Instansi Pemerintah. Kebijakan/prosedur tersebut telah dikomunikasikan ke pegawai yang berkepentingan. Namun demikian, terdapat hal-hal yang memerlukan perbaikan terkait: evaluasi terhadap kebijakan mekanisme perolehan informasi yang belum dilaksanakan secara berkala dan terdokumentasi dan berkala. Tidak terdapat mekanisme pemantauan secara otomatis atau online atas informasi penyelenggaraan SPI di lingkungan Inspektorat Kota Banjarbaru.

2. Komunikasi yang Efektif Penilaian terhadap komunikasi yang efektif telah memenuhi kriteria pada tingkat "Terdefinisi", dengan kondisi : Secara umum, unit organisasi di lingkungan Pemerintah Kota Banjarbaru telah memilki media penyampaian informasi kepada semua pegawai. Terdapat distribusi informasi ke seluruh pegawai yang berkepentingan dan komunikasi antar kegiatan, memiliki whistleblower system untuk penyampaian pengaduan. Namun, masih terdapat area yang perlu peningkatan yaitu evaluasi terhadap mekanisme perolehan informasi yang dilakukan belum secara berkala dan terdokumentasi dengan baik.

\section{e. Pemantauan}

Pemantauan adalah proses penilaian atas mutu kinerja sistem pengendalian intern dan proses yang memberikan keyakinan bahwa temuan audit dan evlausi lainnya segera ditindaklanjuti. Pemantauan dilaksanakan melalui pemantauan berkelanjutan, evaluasi terpisah, dan tindak lanjut rekomendasi hasil audit revieu. Penilaian terhadap pemantauan berkelanjutan telah memenuhi kriteria pada tingkat "Terkelola dan Terukur", dengan kondisi : Inspektorat Kota Banjarbaru telah memiliki SOP mengenai tindak lanjut hasil pemeriksaan, melakukan pelaksanaan pemantauan terhadap penyerapan anggaran, masalah internal (pencapaian keuangan, penyusunan rencana aksi, permasalahan dengan Kementerian/Lembaga lain yang mempengaruhi capaian kinerja), administrasi pertanggungjawaban dan sebagainya. Evaluasi atas kebijakan telah terdokumnetasi secara memadai namun belum terdapat otomatisasi atas kegiatan pemantauan berkelanjutan. Inspektorat Kota Banjarbaru belum memiliki mekanisme untuk meyakinkan ditindaklanjutinya temuan audit atau reviu lainnya dengan segera. Adanya kegiatan konsultasi dengan auditor (seperti BPK, aparat pengawasan intern pemerintah, dan auditor eksternal lainnya) dan pereviu jika diyakini akan membantu dalam proses penyelesaian audit. Data (Sekunder): Dokumen korespondensi 
dengan auditor. Penindaklanjutan atas temuan dan rekomendasi audit dan reviu lainnya dengan tepat. Adanya mekanisme koreksi terhadap masalah yang berkaitan dengan transaksi atau kejadian tertentu. Adanya kegiatan pemantauan temuan audit dan reviu serta rekomendasinya untuk meyakinkan bahwa tindakan yang diperlukan telah dilaksanakan. Dokumen Tindak Lanjut. Laporan/daftar saldo temuan. Adanya laporan status penyelesaian audit dan reviu sehingga pimpinan dapat meyakinkan kualitas dan ketepatan waktu penyelesaian setiap rekomendasi.

\section{Analisis Kapabilitas APIP di Inspektorat Kota Banjarbaru}

Penilaian terhadap Tingkat Kapabilitas APIP dengan target tahun 2016, adalah berdasarkan Laporan Pendampingan Peningkatan Kapabilitas APIP pada Inspektorat Kota Banjarbaru tahun 2016 (Nomor LBA-638/PW16/6/2016). Berdasarkan laporan tersebut dan sampai dengan akhir tahun 2017, APIP Kota Banjarbaru masih berada pada level 2,4 dengan catatan. Pada tahun 2017, sesuai target Kapabilitas APIP ditargetkan masih sama berada pada Level 2. Hal tersebut memperlambat untuk memenuhi pernyataan-pernyataan di Level 3. Hal tersebut dikarenakan kurang koordinasi antar Satgas Peningkatan Kapabilitas APIP dan kurangnya komitmen di lingkup Inspektorat Kota Banjarbaru untuk meningkatkan Level Kapabilitas APIP. Menurut Peraturan Kepala BPKP No. PER1633/K/JF/2011, Kapabiltas APIP adalah kemampuan untuk melaksanakan tugastugas pengawasan yang terdiri atas tiga unsur yang saling terkait, yaitu kapasitas, kewenangan, dan kompetensi SDM APIP yang harus dimiliki APIP agar dapat mewujudkan peran APIP secara efektif.

\section{Audit Berbasis Risiko (RBA)}

Penilaian risiko mengacu pada kegiatan yang tertuang dalam tupoksi dan dokumen pelaksanaan anggarna (DPA) tahun 2017, serta sebagaimana yang telah disepakati dalam beberapa rangkaian Focus Group Discussion (FGD) yang telah dilaksanakan Objek penyelenggaraan SPIP berupa kegiatan yang akan dilakukan penilaian risiko di lingkungan Pemerintah kota Banjarbaru adalah sebagai berikut: Kegiatan yang disampel untuk menentukan penilaian risiko di Inspektorat adalah sebagai berikut: pengawasan internal secara berkala,p enanganan kasus pengaduan di lingkungan pemerintah daerah, tindak lanjut hasil temuan pengawasan, reviu RKA SKPD, evaluasi SPIP, pengawasan inventarisasi asset, tindak lanjut hasil temuan BPK, pengawasan dan pengendalian kas opname SKPD pada akhir tahun, evaluasi LAKIP SKPD, diklat pemeriksa dan aparatur pengawasan.

Pelaksanaan penilaian risiko (identifikasi risiko, analisis risiko sampai dengan rencana tindak pengendalian) dilakukan melalui focus group discussion (FGD) yang bertujuan mengarahkan dan menggali lebih dalam berbagai permasalahan dan wawasan yang dikeluarkan oleh para peserta diskusi dari dinas terkait, sekaligus untuk mengkonfirmasi dan memvalidasi berbagai aspek permasalahan yang dibahas. 
Tabel 2

Skala Dampak Risiko

\begin{tabular}{|c|c|c|}
\hline No & $\begin{array}{l}\text { Kriteria } \\
\text { Dampak }\end{array}$ & Definisi Kriteria Dampak \\
\hline 1 & $\begin{array}{c}\text { Rendah } \\
\text { Sekali }\end{array}$ & $\begin{array}{l}\text { Cukup menggangu jalanan } \\
\text { pelayanan } \\
\text { Menimbulkan kerusakan kecil } \\
\text { Kerugian diatas Rp. } 25 \text { jt- } 100 \\
\text { jt } \\
\text { Terjadi penambahan anggaran } \\
\text { yang tidak diprogramkan } \\
\text { namun tidak lebih dari Rp. } \\
\text { 100 jt } \\
\text { Menggangu pencapaian tujuan } \\
\text { organisasi meskipun tidak } \\
\text { signifikan } \\
\text { Berdampak pada pandangan } \\
\text { negative terhadap institusi } \\
\text { dalam skala local (telah masuk } \\
\text { dalam pemberitaan media } \\
\text { local) kn kerusakan } \\
\text { Adanya kecil } \\
\text { terhadap lingkungan }\end{array}$ \\
\hline 2 & Rendah & $\begin{array}{l}\text { Menggangu kegiatan } \\
\text { pelayanan secara signifikan } \\
\text { Adanya kekerasan, ancaman } \\
\text { dan menimbulkan kerusakan } \\
\text { yang serius } \\
\text { Kerugian yang terjadi diatas } \\
\text { Rp. } 100 \text { jt sampai Rp. } 500 \text { jt } \\
\text { Terjadi penambahan anggaran } \\
\text { yang tidak diprogramkan } \\
\text { namun tidak lebih dari Rp. } \\
500 \text { jt tujuan } \\
\text { Menggangu pencapaian tuan } \\
\text { organisasi secara signifikan } \\
\text { Berdampak pada pandangan } \\
\text { negative terhadap institusi } \\
\text { dalam skla nasional (telah } \\
\text { masuk dalam pemberitaan } \\
\text { media local dan nasional) }\end{array}$ \\
\hline 3 & Tinggi & $\begin{array}{l}\text { Terganggunya pelayanan lebih } \\
\text { dari } 2 \text { hari tetapi kurang dari } 1 \\
\text { minggu } \\
\text { Adanaya kekerasan, ancaman } \\
\text { dan menimbulkan kerusakan }\end{array}$ \\
\hline
\end{tabular}

\begin{tabular}{|c|c|c|}
\hline & & $\begin{array}{l}\text { yang serius dan membutuhkan } \\
\text { perbaikan yang cukup lama } \\
\text { Kreugian yang terjadi diatas } \\
\text { Rp. } 500 \text { jt sampai Rp. } 1 \mathrm{M} \\
\text { Sebagian tujuan organisasi } \\
\text { gagal dilaksanakan } \\
\text { Merusak citra institusi dalam } \\
\text { skala nasional (telah masuk } \\
\text { dalam pemberitaan media } \\
\text { local dan nasional) }\end{array}$ \\
\hline 4 & $\begin{array}{l}\text { Tinggi } \\
\text { Sekali }\end{array}$ & $\begin{array}{l}\text { Terganggunya pelayanan lebih } \\
\text { dari } 1 \text { minggu } \\
\text { Kerusakan fatal } \\
\text { Kerugian yang terjadi diatas } \\
\text { Rp. 1M } \\
\text { Terjadi penambahan anggaran } \\
\text { yang tidak diprogramkan } \\
\text { namun tidak lebih dari Rp. } 2 \mathrm{M} \\
\text { Sebagian besar tujuan } \\
\text { organisasi gagal dilaksanakan } \\
\text { Merusak citra institusi dalam } \\
\text { skala nasional, penggantian } \\
\text { pucuk pimpinan instansi } \\
\text { secara mendadak } \\
\text { Terjadinya KKN dan diproses } \\
\text { secara hokum }\end{array}$ \\
\hline
\end{tabular}

Hasil penilaian risiko Inspektorat Kota banjarbaru dari kegiatan yang dipilih (10) Kegiatan. Jumlah risiko yang dihasilkan: 9 risiko tinggi sekali, Dari Hasil FGD, :11 Risiko tinggi: 3 Risiko rendah, : 0 risiko rendah sekali, Peserta FGD: 10 Orang.

\section{APIP dalam Audit Berbasis Risiko}

Pembina APIP telah melakukan pembinaan untuk penyusunan PKPT berbasis risiko kepada seluruh pejabat di lingkungan Inspektorat Kota Banjarbaru. Penyusunan peta audit ini dibatasi hanya penetapan faktor risiko saja yang bisa dilihat dari beberapa indikator misalnya anggaran, kompleksitas pekerjaan, kualitas SDM dan lokasi. 


\section{Simpulan dan Saran}

\section{Simpulan}

Dari segi efektivitas, proses Sistem Pengendalian Pemerintah (SPIP) di Inspektorat Kota Banjarbaru telah sesuai dengan Peraturan Pemerintah Nomor 60 Tahun 2008 dan Peraturan Walikota Banjarbaru Nomor 44 Tahun 2013, Inspektorat Kota Banjarbaru melaksanakan tugas dan fungsi pembinaan dan pengawasan terhadap jalannya pemerintahan daerah. Metode pengendalian intern yang diterapkan oleh Inspektorat Kota Banjarbaru mengacu pada Audit Berbasis Risiko (RBA). Sistem Pengendalian Intern Pemerintah khususnya di Inspektorat Kota Banjarbaru masih lemah dan dalam pelaksanaannya masih belum optimal. Hal ini dapat dilihat dari beberapa pernyataan di Level 2 yang masih belum terpenuhi. Hal tersebut memperlambat untuk memenuhi pernyataan-pernyataan di Level 3. Hal tersebut dikarenakan kurang koordinasi antar Satgas Peningkatan Kapabilitas APIP dan kurangnya komitmen di lingkup Inspektorat Kota Banjarbaru untuk meningkatkan Level Kapabilitas APIP. Sasaran kegiatan ini adalah membantu inspektorat menyiapkan infrastruktur dalam rangka penerapan tata kelolanya menuju ke level 2 (dua) penuh. Hasil evaluasi pelaksanaan mandiri (self Assesment) oleh inspektorat Kota Banjarbaru triwulan tiga atau pada bulan September 2017 menunjukkan bahwa setiap elemen tata kelola menurut IACM yang dnilai berada pada level yang berbeda yaitu: Level 2 yaitu : Elemen 1 Peran dan Layanan, elemen III Praktek Profesional,elemen IV Akuntabilitas dan Manajemen, elemen V Budaya dan hubungan Organisasi, elemen VI Struktur tata Kelola (Governance Strucures), Level 1 yaitu Elemen 2 : Pengelolaan SDM (People Management). Sebagai tindak lanjut atas hasil evaluasi mandiri tersebut dilaksanakan tahap pendampingan peningkatan kapabilitas APIP. Pada tahap ini dilakukan identifikasi dan analisis area of improvement serta langkah langkah yang harus dilakukan oleh APIP dalam upaya meningkatkan kapabilitas tata kelola untuk menuju level 2 dengan harapan agar seluruh unsur pimpinan dan pegawai Inspektorat Kota Banjarbaru memiliki pemahaman yang sama. Pelaksanaan kegiatan pendampingan peningkatan kapabilitas APIP dilaksanakan dalam bentuk sosialisasi dan bimbingan teknis terhadap APIP di lingkungan Inspektorat Kota Banjarbaru. Pelaksanaan pendampingan pada Inspektorat Kota Banjarbaru dilakukan di Aula Inspektorat Kota Banjarbaru selama 3 (tiga) hari dari tanggal 17 Oktober 2016 sampai dengan 19 Oktober 2016. Pendampingan yang telah dilakukan adalah menyusun PKPT sesuai dengan skala prioritas kegiatan APIP. Pendampingan peningkatan kapabilitas APIP diselenggarakan dengan tujuan untuk memberikan masukan bagi pimpinan instansi pemerintah dalam meningkatkan kapabilitas APIP di lingkungannya. Penilaian terhadap indikator kinerja Tingkat Kapabilitas APIP dengan target tahun 2016, adalah berdasarkan Laporan Pendampingan Peningkatan Kapabilitas APIP pada Inspektorat Kota Banjarbaru tahun 2016 (Nomor LBA-638/PW16/6/2016) Tanggal 29 Desember 2016, yang dilaksanakan sejak tanggal 17 s/d 19 Oktober 2016. Berdasarkan laporan tersebut dan sampai dengan akhir tahun 2017, APIP Kota Banjarbaru masih berada pada level 2 dengan catatan. Pada tahun 2017, sesuai target Kapabilitas APIP ditargetkan masih sama berada pada Level 3. Inspektorat sebagai Satuan Kerja Perangkat Daerah yang menyelenggarakan pengawasan pelaksanaan urusan dan penyelenggaraan pemerintahan daerah serta mampu berperan sebagai institusi yang mampu meningkatkan kualitas pengawasan pelaksanaan pembangunan daerah sehingga dapat mewujudkan tata kelola pemerintahan yang baik (Good Governance) dan 
pemerintahan yang bersih (Clean Government). kedua hal tersebut ikut berkontribusi dalam meningkatkan Gross Domestic Product (GDP), penurunan kemiskinan, dan membantu sektor corporate yang tujuan akhirnya adalah meningkatkan kesejahteraan rakyat. Inspektorat tidak memiliki Standar Pelayanan Minimal (SPM) namun dalam melaksanakan pengawasan berpedoman pada Peraturan Menteri Dalam Negeri Nomor 23 Tahun 2007 tentang Pedoman Tata Cara Pengawasan atas Penyelenggaraan Pemerintahan Daerah yang dirubah dengan Peraturan Menteri Dalam Negeri Nomor 8 Tahun 2009 tentang Perubahan Atas Peraturan Menteri Dalam Negeri Nomor 23 Tahun 2009 Tentang Pedoman Tata Cara Pengawasan Atas Penyelenggaraan Pemerintahan Daerah yang meliputi: Penanganan Pengaduan Masyarakat, Evaluasi Laporan Akuntabilitas Kinerja Instansi Pemerintah untuk mengetahui Sistem Akuntabilitas Kinerja Instansi Pemerintah (SAKIP) dan Pemantauan Tindak Lanjut Hasil Pengawasan.

Hasil pengamanatan dari penilaian risiko di Inspektorat Kota Banjabaru penulis menemukan beberapa indikasi inefisiensi. Sesuai dengan laporan analisis risiko terdapat kekurangan dari pengungkapan lapoan kinerja Inspektorat Kota Banjarbaru tahun 2017 serta kelemahan pelaksanaan fungsi pengawasan yaitu antara lain:

1. Kompetensi dan keahlian Sumber Daya Manusia Aparatur pengawas internal pemerintah (APIP) baik auditor keuangan, auditor Kepegawaian \& P2UPD dan pejabat pengelolaan aset atau barang daerah pada SKPD masih minim

2. APIP belum memiliki kapabilitas yang memadai untuk melaksanakan fungsi pengawasan intern secara efektif, seperti sistem pengelolaan administrasi yang kurang baik.

3. Masih belum memadainya perangkat pendukung teknologi informasi penunjang pelaksanaan pengawasan

4. Intensitas dalam mobilitas pelaksanaan pengawasan masih belum memadai

5. Fasilitas dan sarana prasarana gedung dan kantor belum representatif.

6. Komitmen dan motivasi aparatur pengawas masih harus ditingkatkan khusunya dalam mencapai hasil yang maksimal

7. Temuan yang berulang karena tidak bersungguh-sungguh terhadap penyelesaian tindak lanjut hasil temuan pengawasan;

8. SKPD perlu menyusun perencanaan sebagai sesuatu yang penting dan bukan hanya formalitas

9. Standart Operating Prosedur (SOP) pada setiap SKPD masih belum optimal.

10. Kualitas pelayanan publik yang masih harus ditingkatkan.

Berdasarkan isu permasalahan utama di atas dapat disimpulkan bahwa Pengendalian Internal pada masing-masing di Inspektorat Kota Banjarbaru masih lemah dan kurang efektif. Pengendalian internal pada setiap unit organisasi merupakan faktor yang mendasar sehingga tugas pokok dan fungsi tiap-tiap organisasi agar dapat terlaksana sesuai dengan peraturan perundangundangan yang berlaku. Semakin baik sistem pengendalian internal pemerintah maka semakin efektif dalam mencapai visi dan misi pemrintah. Didukung oleh penguatan internal kontrol yaitu intergritas, etika, moralitas, kejujuran, dan keteladanan dari pimpinan serta aparat pemerintah yang akan menghasilkan trust atau kepercayaan dari masyarakat.

\section{Saran}

Keberhasilan pelaksanaan kegiatan pada Inspektorat Kota Banjarbaru tidak hanya tergantung dari dukungan Pimpinan Daerah dan seluruh organisasi Perangkat Daerah Kota Banjarbaru, tetapi juga atas partisipasi, 
sikap mental, semangat, ketaatan, disiplin, serta kejujuran aparat dilingkungan Inspektorat Kota Banjarbaru sendiri. Melihat dari tantangan yang ada, maka peluang atas hasil analisis pencapaian kinerja pada Tahun 2017, dapat dirumuskan beberapa langkah penting sebagai strategi pemecahan masalah yang akan dijadikan masukan atau sebagai bahan pertimbangan bagi Inspektorat untuk mewujudkan visinya sebagai "Pengawas Yang Berintegritas" yaitu sebagai berikut.: mempertegas kembali komitmen Walikota Banjarbaru terpilih dan SKPD dalam menindak lanjuti rekomendasi yang belum/masih dalam proses penyelesaian khusunya pembenahan kebijakan dalam hal pengawassan, melakukan pengawasan yang intensif melalui kegiatan monitoring tindak lanjut temuan pengawasan, PKPT dan RT, menjalin hubungan yang lebih intens kepada Lembaga Pengawas Exsternal dalam hal ini BPKP perwakilan Kalimantan Selatan dalam upaya mendukung peningkatan level Maturitas SPIP dan Tingkat Kapabilitas APIP Kota Banjarbaru, memberikan peluang pembinaan kompetensi yang lebih optimal untuk SKPD. Memaksimalkan pemeriksaan kinerja atau reguler terhadap SKPD dengan titik berat untuk pelaksanaan Rencana Pembangunan Jangka Menengah Daerah (RPJMD) di lingkungan pemerintah Kab/Kota Banjarbaru serta pemeriksaan pengelolaan keuangan dan asset, selalu melaksanakan review LKPD dalam rangka mempertahankan Opini Wajar Tanpa Pengecualian ( WTP ), serta pemeriksaan rutin terhadap Evaluasi secara berkala penerapan Sistem Pengendalian Internal Pemerintah (SPIP), meningkatkan kompetensi, motivasi, dan peran APIP Inspektorat Kota Banjarbaru sebagai Quality Assurancce dan agen perubahan serta mampu menyiapkan Piagam Audit Intern (Audit harter).

\section{Daftar Pustaka}

Arens, Alvin A, Elder, Randal J, \& Beasly, Mark S. (2011). Auditing and Assurance Services, An Integrated Approach (13 ${ }^{\text {th }}$ ed $)$ Pearson Prentice Hall; New Jersey.

BAPEPAM. 2004. Keputusan Ketua Badan Pengawas Pasar Modal. No Kep 29/PM/2004 (Peraturan No IX.I.5) tentang Pembentukan dan Pedoman Pelaksanaan Kerja Komite Audit.

Cendrowski H and C Mair William. 2009. Enterprise Risk Management and Coso. John Wiley \& Sons, Inc; New Jersey.

COSO ERM Integrated Framework. (2004) by the Committee of Sponsoring Organizations of the Treadway Commission.

Dadang Kurnia, "Transformasi Fungsi Audit Intern Pemerintah: meningkatkan Kapabilitas APIP"

Deputi Kepala BPKP Bidang Pengawasan Penyelenggaraan Keuangan Daerah " Peningkatan Maturitas SPIP dan Kapabilitas APIP” Rapat Koordinasi Nasional APIP 23 Agustus Tahun 2016. Jakarta

Dwi Waracanova, Sartika. 2012. Tesis yang Berjudul "Analisis Peranan Audit Internal Terhadap Corporate Governance, Manajemen Risiko dan Pengendalian Internal" Studi Kasus pada PT XYZ. Universitas Indonesia.

General Accounting Ofice (GAO). (1999). Standards For Internal Control in The Federal Government. Author; Washington, DC.

Haerul Triyanto 2017. Skripsi yang berjudul "Pengaruh Kompetensi Sumber Daya Manusia, Pengendalian Internal, Pemanfaatan teknologi Informasi dan Peran Inspektorat Daerah Terhadap Kualitas Laporan Keuangan Daerah (Studi Empiris Pada Satuan Kerja Perangkat Daerah Kabupaten Kulon 
Progo)".

Muhammadiyah Yogyakarta

http://www.adb.org/Document/Manuals/

Serve andPreserve/Chapter09.PDF.

Inspektur Kota Banajarbaru Nomor

23 Tahun 2016 tentang RENSTRA

Inspektorat Kota Banjarbaru Tahun 2016-2021

Ikatan Akuntan Indonesia. 2011. Standar Profesional Akuntan Publik. IAI; Jakarta

Kalakota, Ravi and Robinson, Marcia. (2001). Ebusiness Model 2.0: Roadmap For Success. AddisonWesley.

Keputusan Inspektur Kota Banjarbaru Nomor 023 Tahun 2016 tentang Rencana Strategis (RENSTRA) Inspektorat Kota Banjarbaru Tahun 2016-2021;

K.H Spencer Picket. 2004.The Internal Auditor At Work, A Practical Guide to Everyday Challenger. Jhon Willey\&Sons; New Jersey.

Konrath, Larry F. (2002). Auditing: A Risk Analysis Approach $\left(5^{\text {th }} \mathrm{ed}\right)$. Thomson Learning: South Western.

La Midjan. 2001. Sistem Informasi Akuntansi I Pendekatan Manual Penyusunan Metode dan Prosedur. Lingga Jaya; Bandung.

Mardiasmo.(2004). Akuntansi Sektor Publik. Andi; Yogyakarta

Materi PPT, disampaikan oleh Emharri Manda Nasution, SE MM 'Audit Berbasis Resiko", Bogor 2016

Moeller, Robert R. 2009. Brinks Modern Internal Auditing A Common Body Of Knowledge ( $7^{\text {th }}$ ed). John Wiley dan Sons, Inc; New Jersey.

_ _ _ _ _ _ _ _ _ _2009. Brinks

Modern Internal Auditing. Sixth

Edition. John Wiley dan Sons, Inc;

New Jersey

Pedoman pemetaan SPIP di lingkungan Pemerintah

Peraturan BPK Nomor 1 Tahun 2017 tentang Standar Keuangan Negara
Peraturan Gubernur Kalimantan Selatan Nomor 83 Tahun 2017 tentang Tugas pokok, fungsi dan uraian tugas Inspektorat daerah Provinsi Kalimantan Selatan

Peraturan Menteri Komunikasi dan Indormatika Republik Indonesia Nomor 30 Tahun 2015 Tentang Pedoman Penyelenggaraan Sistem Pengendalian Intern Pemerintah di Lingkungan Kementrian

Komunikasi dan Informatika.

Peraturan Pemerintah Republik Indonesia

Nomor 60 Tahun 2008 tentang

Sistem Pengendalian Intern

Pemerintah

Peraturan pemerintah Nomor 8 Tahun 2008 tentang Tahapan, Tata cara Penyusunan. Pengendalian dan Evaluasi Rencana Pembangunan Daerah, Satuan Kerja Perangkat Daerah (SKPD) wajib menyusun Rencana Kerja.

Peraturan Pemerintah (PP) Nomor 18 Tahun 2016 tentang Perangkat Daerah (Lembaran Negara Republik Indonesia Tahun 2016 Nomor 114

Peraturan Kepala Badan Pengawasan Keuangan dan Pembangunan Nomor 25 Tahun 2013 tentang Petunjuk Pelaksanaan Control Envionment Evaluation (CEE)

Peraturan Walikota Banjarbaru Nomor 56 Tahun 2016 "Kedudukan, Susunan Organisasi, Tugas dan Fungsi, Serta Tata kerja Inspektorat Kota Banjarbaru.

Peraturan Walikota Banjarbaru Nomor 44 Tahun 2013 tentang Tugas Pokok, Fungsi dan Tata Kerja Inspektorat Kota Banjarbaru.

Peraturan Daerah Kota Banjarbaru Nomor 11 tahun 2011 tentang Rencana Pembanguan Jangka Panjang Daerah (RPJPD) Kota Banjarbaru tahun 2005 - 2025 (Lembaran Daerah Kota Banjarbaru Tahun 2011 Nomor 11); 
Peraturan Daerah Kota Banjarbaru Nomor 14 Tahun 2011 tentang Rencana Pembangunan Jangka Menengah Daerah (RPJMD) Kota Banjarbaru Tahun 2011 - 2015 (Lembaran Daerah Kota Banjarbaru Tahun 2011 Nomor 14, Tambahan Lembaran Daerah Kota Banjarbaru Nomor 13);

Peraturan daerah Nomor 11 Tahun 2010 tentang Rencana Pembangunan Jangka Panjang Daerah (RPJPD) Kota Banjarbaru Tahun 2005-2025;

Peraturan Daerah Nomor 7 Tahun 2016 tentang Rencana Pembangunan Jangka Menengah Daerah (RPJMD) Kota Banjarbaru Tahun 2016-2021;

Pemerintah Indonesia. 2002. Keputusan Menteri Badan Usaha Milik Negara No 117/M MBU/2002 tentang Penerapan Praktik Good Corporate Governance pada BUMN.

Peraturan Kepala Badan Pengawasan Keuangan dan Pembangunan Nomor 25 Tahun 2013 tentang Petunjuk Pelaksanaan Control Envionment Evaluation (CEE)

Pickett, K.H, Spencer. 2005. The Essential Handbook of Internal Auditing. John Wiley and Sons, Inc; New Jersey.

Romney, Marshal. B and Steinbart, Paul John. (2000). Accounting Information Systems. ( $8^{\text {th }}$ ed).

Sawyer's, (2012). Internal Audit Essentials $\left(6^{\text {th }}\right.$ ed Volume 1). The IIA Research Foundation; Florida

Sawyer's, (2012). Internal Audit Processess and Methods $\left(6^{\text {th }}\right.$ ed Volume 2). The IIA Research Foundation; Florida

Sawyer's, (2012). Governance Risk Management, and Compliance
Essentials (6 $6^{\text {th }}$ ed Volume 3). The IIA Research Foundation; Florida

Schiavo-Campo, S dan Sundaran, Pachampet Sabhesa Aiyar. (2001). To Serve and to Preserve: Improving Public Administration in a Competitive Worls. Asian Development Bank February 8, 2011; Manila.

Situs resmi Inspektorat Kota Banjarbaru

Standar Profesi Audit Internal. 2008. Yayasan Pendidikan Internal Audit; Jakarta

The IIA Practice Advisories Under International Professional Practice Framework (IPPF)

The IIA : Standard for the Professional Practice of Internal Auditing and related IIA publication

The Institute of Risk Management. 2012. A Risk Management Standar 6 Januari 2012. http://www.theirm.org/publications /documents/ Risk Management Standar 030820.pdf

The Risk Metrics Group (1998), Exploring Risk and Managing Risk (http://www.bexi.co.id/images/_res /perbankanKerangka\%20Kerja\%2 0Risk\%20 Management.pdf)

Tuanakotta, Theodurus M, (2013). Audit Berbasis ISA. Salemba Empat; Jakarta

Undang-Undang Nomor 32 Tahun 2004 tentang Pemerintahan Daerah (Lembaran Negara Republik Indonesia Tahun 2004 Nomor 125, Tambahan Lembaran Negara Republik Indonesia Nomor 4437) sebagaimana telah diubah beberapa kali terakhir dengan UndangUndang Nomor 12 Tahun 2008 (Lembaran Negara Republik Indonesia Tahun 2008 Nomor 59, Tambahan Lembaran Negara Republik Indonesia Nomor 4844)

Wondabio, L, Sensi. 2010. Internal Audit Berbasis Risiko (Risk Based Audit): Bagi Perusahaan Asuransi 
Jurnal Akuntansi Maranathan Volume 10 Nomor 2, November 2018 : 117-138

Kerugian (Umum), Asuransi Jiwa dan Reasuransi. CT Prima Consulting \& Training; Jakarta.

Widya Pratiwi. 2012. Analisis Penerapan

Sistem Pengendalian Intern (Studi

Kasus: Pemerintah Kabupaten

Bungo).

www.lontar.ui.ac.id/file?file=digital/119845

$-\mathrm{T} \% 2025278$

Studi\%20kasus\%20pengendalian-

Literatur.pdf

www.theiia.org

www.Vijayinspektoratbanjarbaru.blogspot.

co.id 